\title{
Conditions for Unethical Environmental Behaviour in Organizations
}

\section{Uwarunkowania nieetycznego zachowania wobec środowiska w organizacjach}

\author{
Marek Bugdol $^{\star}$, Daniel Puciato**, Tadeusz Borys ${ }^{\star \star \star}$ \\ *Jagiellonian University, Kraków, Poland \\ E-mail: marek.bugdol@uj.edu.pl \\ **WSB University in Wroctaw, Wrocław, Poland \\ E-mail: daniel.puciato@wsb.wroclaw.pl \\ ***University of Zielona Góra, Zielona Góra, Poland \\ E-mail:t.borys@wez.uz.zgora.pl
}

\begin{abstract}
The objective of the paper is to identify and classify the conditions for unethical environmental behaviour. It has been shown that the primary condition for unethical environmental behaviour is the level of environmental ethics dominant in a community and the observed inconsistency between the declared level of this ethics and the practice of business, institutional (including legal), social, market, etc. behaviour towards the environment. The observed axiological inconsistency generates numerous external and internal phenomena (factors, conditions) that create fertile ground for unethical activities leading to environmental degradation. The external conditions comprise, among others, complicated tax systems, subsidy and subvention systems and prices of emission allowances. The short term perspective of enterprises, the decreasing average working time of managers, a crisis of ethical leadership and a low level of responsibility for the environment have been identified as the most important internal conditions. Unethical environmental behaviour is further intensified in the absence of control and external reaction to its occurrence.
\end{abstract}

Key words: environmental ethics, environmental behaviour, unethical behaviour, conditions, enterprises

\section{Streszczenie}

Celem artykułu jest identyfikacja i klasyfikacja uwarunkowań nieetycznych zachowań środowiskowych. Wykazano, że głównym, źródłowym uwarunkowaniem nieetycznych zachowań wobec środowiska jest dominujący w danym społeczeństwie poziom etyki środowiskowej oraz obserwowane zjawisko niezgodności między deklarowanym poziomem tej etyki a praktyką zachowań wobec środowiska - zachowań biznesowych, instytucjonalnych (w tym prawnych), społecznych, rynkowych itp. Zaobserwowane zjawisko niezgodności aksjologicznej generuje liczne pochodne zjawiska (czynniki, uwarunkowania) zewnętrzne i wewnętrzne, stwarzające podatny grunt dla działań nieetycznych, degradujących środowisko przyrodnicze. Wśród uwarunkowań zewnętrznych zidentyfikowano m.in. skomplikowane systemy podatkowe, systemy dotacji i subwencji oraz rozbieżne ceny emisyjne. Za najważniejsze uwarunkowania wewnętrzne uznano m.in. krótkookresową optykę przedsiębiorstwa, zmniejszający się przeciętny czas pracy menedżerów, kryzys etycznego przywództwa i niski poziom odpowiedzialności za środowisko. Nieetyczne zachowania środowiskowe są dodatkowo wzmacniane w sytuacji braku kontroli i reakcji zewnętrznej na takie zachowania.

Słowa kluczowe: etyka środowiskowa, zachowania środowiskowe, zachowania nieetyczne, uwarunkowania, przedsiębiorstwa 


\section{Introduction}

For many years, two opposite tendencies in the contemporary enterprises' development of relations with the environment have been visible in the field of management sciences. Some enterprises consider - not only declaratively - environmental issues to be important and take a number of ethical pro-environmental actions aimed at minimizing their negative impact on the natural environment. They implement the concept of Total Quality Environmental Management (TQEM) and apply the principles of green supply chains, green human resources, green investments, etc. The countertendency in the approach to environmental protection is manifested in the fact that some enterprises treat it instrumentally, and short term costs and revenues are the main reasons for taking, or refraining from taking, specific pro-environmental actions. Unethical but pro-organizational behaviour often occurs in such enterprises (Umphress, Bingham, 2011). In the opinion of the authors of this paper, four types of behaviour deserve special attention:

1. Greenwashing, a problem studied so far from the perspective of advertising and consumer perception (Schmuck et al., 2018; Topal et al., 2020; Zhang et al., 2019), the causes (De Jong et al., 2018; Lee et al., 2018; Testa et al., 2018) and the consequences of such behaviour (More, 2019; De Jong et al., 2018; De Jong et al., 2020; Torelli et al., 2020).

2. Carbon leakage, a problem analysed in the literature on the subject mainly due to its causes and related risks (Gurtu et al., 2016; Santos et al., 2019; Sommer, Kratena, 2020), the measurement methodology (Zhang, Fang, 2019) and business justifications for such environmental behaviour (Van der Ploeg, 2016).

3. Offshoring, analysed most often in the context of the relationship between the owner and the contractor (Qiao, 2019), the factors influencing the choice of its optimal form (Tomiura, 2009) and the role of organizational values and failures related to its application (Aron, Singh, 2005; Kelly, Noonan, 2008).

4. Unethical lobbying, previously considered in terms of the reasons for its use (Kim, 2019) and impact on organizational performance (Baron, 1995).

It should be stressed that, in the field of management sciences, the problems of environmental ethics and awareness as a key determinant of unethical actions towards the environment continue to be underestimated, despite considerable achievements of environmental ethics in philosophical sciences (Epting, 2018; Rolston, 2012a; Rolston, 2012b; Stables, 2020). In management-related works, attention is mainly paid to the problem of ethics in undertaking investment and development activities with potential impact on the environment (Besha et al., 2020;
Damian et al., 2019) and ethical problems accompanying the setting of emission reduction targets (Dahlmann et al., 2019).

None of the works published so far has presented a taxonomy of conditions for unethical anti-environmental actions of persons managing enterprises, taking into account the cause-and-effect cycle, i.e. the division into primary conditions (causes) and secondary conditions (causes and effects), as well as external and internal conditions. It is, therefore, a research gap identified in the cognitive and applicative dimensions. The objective of this paper is to bridge this gap by pursuing the achievement of the following four supporting goals:

1. Presenting the fundamental role (as the primary cause) of the axiological background of unethical environmental behaviour, i.e. value systems in the context of environmental ethics and awareness.

2. Identifying and classifying external and internal conditions derivative of a value system and facilitating unethical environmental behaviour.

3. Conducting an analysis of the four selected types of unethical environmental behaviour: greenwashing, carbon leakage, offshoring and unethical lobbying.

4. Indicating new fields of research within the framework of the issues analysed in this paper.

\section{Research methodology}

The main research method used by the authors was a literature review. The literature on the subject was reviewed in the course of the following stages: (1) selecting the key words: unethical behaviour, carbon leakage, greenwashing, overseas outsourcing, offshoring, lobbying, decision, counterproductive behaviour, (2) searching databases for works containing the identified key words, (3) becoming familiar with the returned publications, (4) reviewing the publications, (5) preparing a map of the available literature, (6) summarizing the selected publications and (7) arranging the collected research material. The applied procedure is consistent with the general methodology of conducting research (Craswell, 2013; Easterby-Smith et al., 2015). The systematic literature review was supplemented with an analysis of the available grey literature (Adams et al., 2016).

\section{A house graph of conditions facilitating un- ethical environmental behaviour}

The concept of the house graph of conditions facilitating unethical environmental behaviour presented in Figure 1 is based on two important methodological assumptions that are worth emphasizing.

Firstly, it is based on recognizing the axiological background of such behaviour as a key condition generating other derivative conditions, both external and internal ones. It is worth noting that, in the pre- 


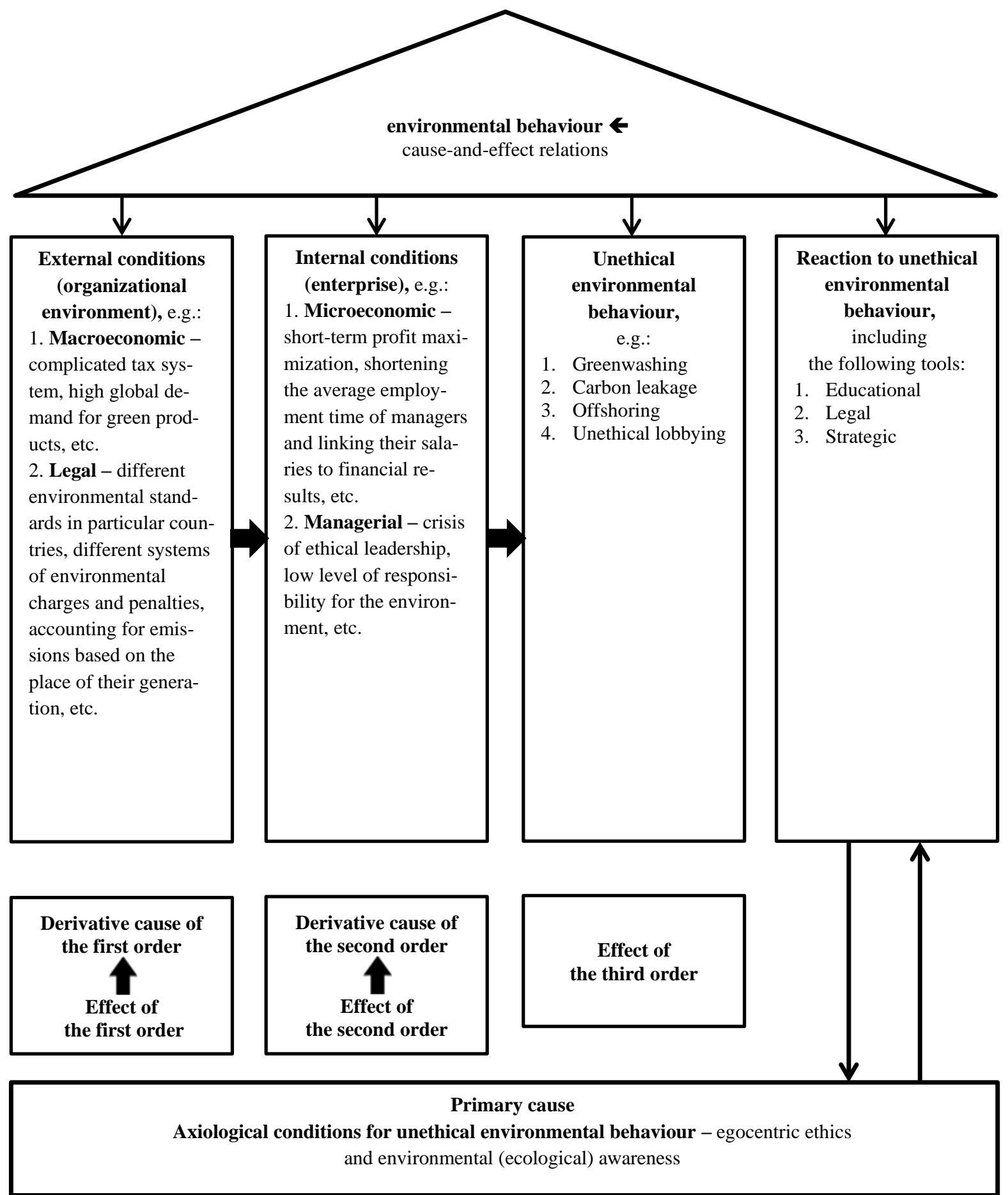

Figure 1. A "house" graph of the conditions for unethical environmental behaviour in an enterprise - cause-and-effect relations, source: the authors' own work.

vious approaches to the identification of the conditions of unethical environmental behaviour, the ethical and moral conditions were predominantly treated on an equal footing with other types of conditions, especially those manifesting themselves in the division into external and internal ones (Kinzig et al., 2013). There are many analogies to the approach to the concept of corporate social responsibility presented in many works, in which ethical and moral responsibility is regarded the same as economic, financial, legal, social and environmental responsibility (Simpson, Kohers, 2002). A different approach to corporate social responsibility will be applied to the process of identifying the conditions of unethical environmental behaviour. It was presented, among others, in the works of T. Borys $(2011,2014)$, in which the four types of responsibility are filtered through ethical and moral responsibil- 
ity, which is of fundamental importance for other components of CSR.

Secondly, it is based on the use of the cause-and-effect analysis in the process of identifying a set of conditions of unethical environmental behaviour and the application of the three key categories of this analysis, i.e. cause (sources, factors, determinants, premises, etc.), effect (consequence, result, outcome, etc.) as well as reactions to effects and causes. This analysis, as proposed by T. Borys (2006), consists in creating a shorter or longer sequence of causes and effects and determining the final element of this sequence, i.e. the reaction. In the course of this sequence, the successive effects of the primary cause, i.e. the effects of a higher order, become in fact the causes of the effects of a lower order.

This explanation is of key importance for the construction and concretization of the cause-and-effect sequence in the analysis of unethical environmental behaviour. It is assumed in this paper that cause-andeffect sequences for this phenomenon are created first of all by axiological conditioning as a primary (fundamental) cause determining all other elements of a cause-and-effect sequence (Fig. 1), i.e.

- external conditions for unethical environmental behaviour as an effect of the first order and a cause of the same order for internal conditions,

- internal conditions for such behaviour as an effect of the second order and a cause of the same order for unethical environmental behaviour itself, which constitutes, in this respect, effects of the third order,

- the concept and form of reaction to external and internal conditions and to unethical environmental behaviour itself.

The subsequent parts of this paper will be devoted respectively to the following:

- a presentation of the axiological background of unethical environmental behaviour, i.e. the fundamental conditions for such behaviour,

- an identification of the main manifestations of unethical environmental behaviour,

- a more detailed analysis of such manifestations in the context of the external and internal conditions for their occurrence.

\section{Axiological background of unethical en- vironmental behaviour}

The axiological condition for unethical environmental behaviour is the fundamental cause of this behaviour determining all the other elements of the causeand-effect sequence shown in Figure 1. In the entire sequence of conditions fostering unethical behaviour and reactions to it, there are people with specific ethics and morality, i.e. people representing a particular system of values and level of awareness.

A system of values relating to man's behaviour towards the natural environment and expressing man's attitude to the surrounding nature is the subject matter of environmental ethics.

The division of behaviour into ethical or unethical is crucial for this paper and needs to be clarified because different types (levels) of environmental ethics have developed, depending on the adopted (egocentric or supra-egocentric) value system. As a consequence, behaviour towards the environment considered to be ethical in one value system (e.g. the egocentric one) may be considered as unethical in another system (e.g. the supra-egocentric one). Therefore, this relativization of assessments of behaviour towards the environment requires the determination of the kind of ethics being the basis for considering a specific behaviour as unethical, stressing that all varieties of environmental ethics focus on the ethical-moral foundations of man's responsibility for actions in the environment and attempt to determine how far this responsibility extends. Each type of this ethics, however, provides a different answer to this fundamental question.

Over the past fifty years, three main trends have crystallized within environmental ethics: anthropocentric (including egocentric), biocentric and ecocentric. The patocentric and cosmocentric trends have been omitted in this paper as less relevant to its objectives. Figure 2 shows the key perspectives related to the recognition of certain types of behaviour towards the environment as unethical, i.e. the width of the ethical field determining a type of environmental ethics and level of ecological awareness adequate to this width, the hypothetical distribution of the human population considering a given ethical field as the basis of its reference to the natural environment and the frequency of recognizing behaviour towards the environment as unethical.

Currently prevailing in environmental ethics, anthropocentrism is a view that recognizes human needs (interests, well-being) and values as the main reference point for any moral valuation. Human needs are more important than the needs of non-human beings, both animate and inanimate (Ganowicz-Bączyk, 2015). However, this trend is not homogeneous, as it is characterized above all by egocentric environmental ethics (or rather an illusion of ethics), based on strong (absolute) anthropocentrism, in which only man has an inner value, while other species and the entire planet have only utilitarian value for the achievement of human goals (Konstańczak, 2008). This ethics is defined by a very narrow ethical plane (ethical field) that assumes the ethical subjectivity of only that part of society with which we currently identify, that is to say, it has a very clearly limited temporal perspective (the current generation), without reflecting on the quality of life of future generations, and an exploitative approach to the environment and its natural resources. Here, too, a rather absurd assumption is made, from the point of view of the vision of man, that man is guided mainly by the logic of such emotions as greed, egoism, cupidity, 


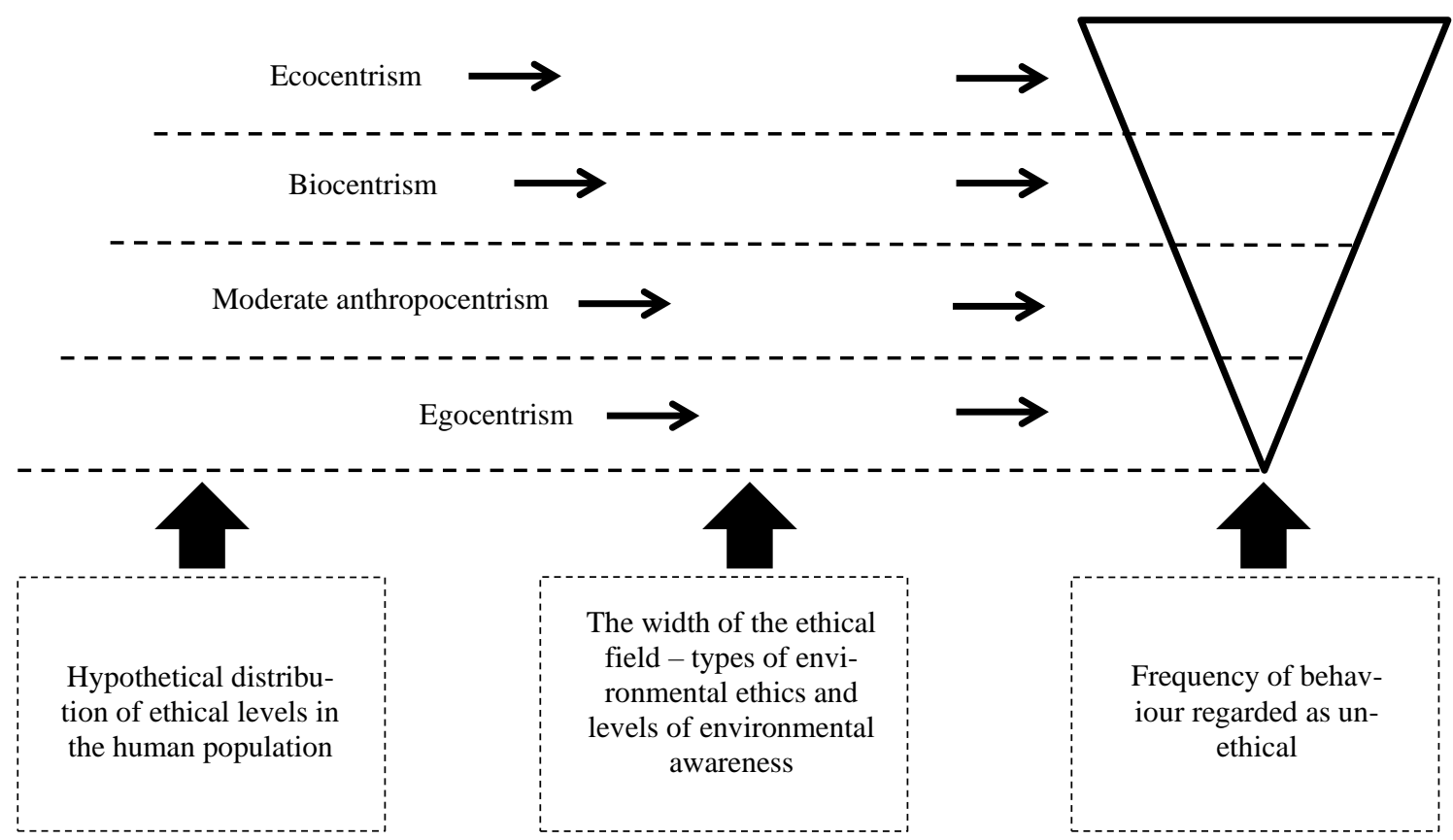

Figure 2. Unethical environmental behaviour and the width of the ethical field, source: the authors' own work.

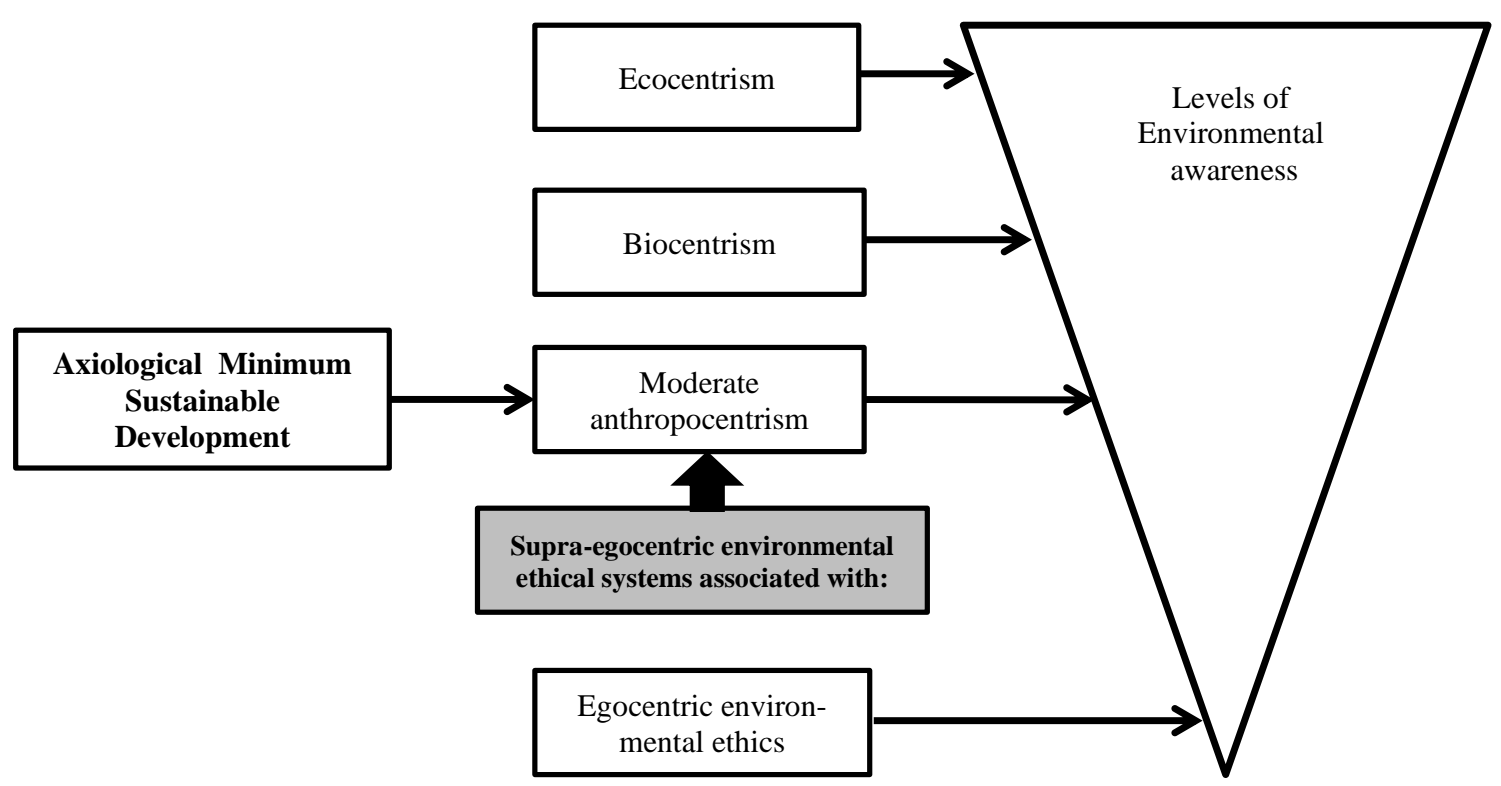

Figure 3. Egocentric and supra-egocentric environmental ethical systems and the level of environmental awareness, source: the authors' own work.

pride, etc., i.e. man is by nature an egocentric (with exuberant ego) and cannot be different, and the notions of good and evil are relativized and conditional; therefore, morality is determined by conditions (Skolimowski, 1981).

It can be seen that egocentrism, as if by its very nature, multiplies unethical environmental behaviour without reflecting on the consequences of such behaviour and without a sense of guilt or shame. A constitutive feature of egocentrism is a low level of ecological awareness which, according to A. Papuziński (2006), can be defined as the entirety of accepted ideas, values and opinions about the environment as the place of life and development of man and society (cf. Fig. 2 and 3) which plays a key role as a primary cause in shaping and disseminating unethical environmental behaviour. Some research shows clearly the direct impact of this awareness on such behaviour of employees in enterprises (Safari et al., 2018). The results of some research also indicate the role of egocentric value systems (or rather anti-value systems) as important generators of unethical environmental behaviour. It often occurs in the absence of moral motives (Gatersleben et al., 2019), properly shaped connections to nature (Whitburn et al., 2020), appropriate personal and social standards (Kinzig et 
al., 2013) and an organizational value system (Zhang, 2020). Although the identified axiological factors have an important cultural and educational background, the consolidation and development of negative behaviour also takes place when there are no appropriate behavioural patterns from other participants, especially leaders (Kinzig et al., 2013). It should be noted that egocentrism also marks the boundary from which, with the expanding ethical field, constructions and messages from the supraegocentric environmental ethical systems start to emerge (Fig. 3).

A special role is played here by environmental ethics based on moderate (weak, relative) anthropocentrism in which both humans and other living beings together with the environment have an intrinsic value, but the value of humans is incomparably higher than the value of the remaining part of nature. Humans have the right to secure their basic needs, i.e. food, water, shelter, sanitation, health care and education, but their implementation should not have a destructive impact on the health and integrity of ecosystems (Ganowicz-Bączyk, 2015, Passmore, 1974).

It can be seen that moderately anthropocentric environmental ethics is defined by an ethical plane broader than egocentrism and recognizing the ethical subjectivity of each individual regardless of the time perspective (present and future generations), gender, race, religion or age. This type of environmental ethics recognizes the fundamental principle of sustainable development, namely the principle of intergenerational justice. This kind of anthropocentrism also defines the axiological minimum of the new development paradigm (Fig. 3) and presupposes a correspondence between what man as an empathetic being feels, thinks, says and accomplishes. This also creates a compatibility in man's relations with nature, i.e. man's ethical environmental behaviour that takes place in the current reality.

In this reality, however, unethical environmental behaviour also occurs, based either on egocentric, destructive thinking and acting towards the environment or being a manifestation of a kind of individual or collective schizophrenia that becomes increasingly evident in the successive empathetic but futile declarations of the need and even the necessity to protect the environment, in the absence of actual ethical environmental behaviour in practice. This axiological dissonance between the pro-environmental empathetic declaration creating artificial and false images for show and egocentric performance is still quite common. Examples of such unethical environmental behaviour will be described in the next chapter.

\section{Main manifestations of unethical activities of enterprises}

Enterprises may undertake various activities aimed at satisfying their own interests, which will not necessarily be beneficial to the environment. Most publications focus on the following four types of behaviour: greenwashing, carbon leakage, offshoring and unethical lobbying.

Greenwashing, less commonly referred to as greenwash, green eyewash or green lie, is the process of giving customers looking for goods produced in accordance with the principles of ecology and environmental protection the impression that given goods or their manufacturer are environmentally friendly. The term refers to misleading messages that aim to create overly positive beliefs among stakeholders about a company's environmental practices (Torell et al., 2020). Enterprises use different tactics in this regard. Some provide false information, while others use half-truths to give false information about selected aspects of a product, e.g. its functional characteristics (De Jong et al., 2020).

Carbon leakage consists in transferring carbon dioxide emissions from one country to another. Carbon leakage occurs when, as a result of a restrictive climate policy concerning $\mathrm{CO}_{2}$ emissions reduction in one country, carbon-intensive production is transferred outside the borders of the country or the European Union to countries where such restrictions do not exist or are less costly. As a result, global $\mathrm{CO}_{2}$ emissions do not decline, and may even increase when a new location uses production methods that generate more $\mathrm{CO}_{2}$ per tonne of a given product (Gąska at al., 2019).

Carbon leakage has become a major problem for emissions trading systems in recent years (Sun et al., 2019). However, studies ordered by the European Commission after the completion of Phase II of the EU ETS have not shown the occurrence of a noticeable carbon leakage from the countries covered by this system (European Union, 2020). Data also indicate a serious leakage of $\mathrm{CO}_{2}$ emissions from developed countries to developing countries (Zhang, Fang, 2019). The transfer of greenhouse gases, in particular $\mathrm{CO}_{2}$, due to international trade is a phenomenon related to classical carbon leakage. It is referred to as the export of embodied emissions.

Another unethical practice is overseas outsourcing, or offshoring. With regard to environmental issues, it involves the transfer of selected processes, not only those related to $\mathrm{CO}_{2}$ emissions, to countries with lower environmental costs and less stringent environmental standards (Andreessen, 2004; Li, Zhou, 2017). Production and service processes are also often transferred to countries characterized by low levels of economic development and more liberal environmental regulations (Taylor, 2005). 
Lobbying as an environmentally unethical activity has a smaller scope and frequency than the three types of unethical behaviour discussed earlier. In general, lobbying is one of the political strategies implemented by enterprises for favourable treatment or a reduction of uncertainty arising from the regulatory environment (Kim, 2019). Lobbying is an activeity undertaken in a non-market environment in order to create value by improving overall performance (Baron, 1995).

Lobbying may be secret or public (Laboutková, Vymětal, 2019). The problem arises when secret, and therefore non-transparent, lobbying takes place as it can give rise to environmentally unethical lobbying behaviour. Examples of ethically questionable behaviour include the lobbying of passenger car manufacturers during the coronavirus pandemic in order to avert environmental standards related to $\mathrm{CO}_{2}$ emissions reduction (The Guardian, 2020).

\section{External conditions}

The external conditions favouring greenwashing or carbon leakage practices are primarily of a macroeconomic and legal nature.

Greenwashing occurs when a company has something to hide, when the actual values of environmental performance and efficiency ratios differ adversely from the normative values or those communicated to the general public (Jones et al., 2019). There are several main reasons for this unethical phenomenon. Some authors note that it is the marketing success of green products that has led to the phenomenon of green laundering (De Jong et al., 2018). However, this problem can also be seen in a broader context, namely, profits that companies generate due to the application of the Corporate Social Responsibility (CSR) principles. Recently, there has been a lively discussion on CSR, and the concept itself has aroused many emotions, both positive and negative. The main objection is that an enterprise's intentions and motivations do not always result from business ethics, but from a narrowly understood economic balance, and CSR is only one way to improve financial performance. Companies usually try to publicize the fact that they are socially responsible (Lee et al., 2018).

In some research, the importance of the pressure exerted by different stakeholder groups on the application of green practices is also taken into account. For example, research carried out by Testa et al. (2018) has shown that pressure from suppliers and shareholders contributes to the ecologization of corporations, and pressure from customers and industrial associations usually encourages green laundering.

External conditions are also largely responsible for the practice of carbon leakage. In the literature on the subject, the following aspects are emphasized in particular: the lack of equal globally binding GHGs, emission reduction targets, diverging GHG emission prices or even their absence in some countries (Gąska et al., 2019). Current practices of accounting for emissions are production-based, which guarantees their incomplete calculations in national emission inventories. This is when outsourcing occurs, which is the cause of increasing global emissions (Gurtu et al., 2016). Views on the impact of some legal regulations on carbon leakage are divergent. Some authors believe that there is no evidence that the EU Emissions Trading System (EU ETS) causes carbon leakage (Naegele, Zaklan, 2019). However, there is fundamental consensus that the risk of carbon leakage is higher in the case of energy-intensive industries.

The carbon leakage inclination depends not only on emission prices, but also on the tax system (Sommer, Kratena, 2020). Some countries have carbon or hydrocarbon taxes. However, not all taxes are fiscally neutral and have an incentive effect, especially if their rates are low. The concern about the potential use of carbon leakage leads to actions aimed at the development of effective emissions valuation instruments. However, carbon leakage risk assessment is still neglected in many countries (Santos et al., 2019).

The main reasons for offshoring include in particular tax incentives, government subsidies for labour costs and access to skilled and available workforce (Jordan et al., 2014). However, it should be assumed that one of the hidden causes of this phenomenon is the attempt to bypass restrictive environmental laws in many countries. This thesis is confirmed by the results of studies carried out by Li and Zhou (2017), which show that the four main anthropogenic air pollutants (sulphur dioxide, nitrogen oxide, carbon monoxide and soot) emitted in China are linked to the production of goods for export. The problem arises particularly in legal systems where there are restrictive environmental laws and liberal economic laws (Taylor, 2005).

In the case of unethical lobbying, the problem is not only enterprises' attempts to influence the legislative process, but the very fact of their participation in the process, e.g. producer associations (Lock, Seele, 2016). On the one hand, companies communicate that they are oriented towards green practices, while on the other hand, they are not interested in revealing their relations with governments and lobbying groups (Winston, 2019).

\section{Internal conditions}

The internal conditions for taking unethical actions are primarily related to people who have an influence on management, i.e. top managers and owners. The mere existence of external conditions favouring unethical behaviour does not mean that such behaviour will be adopted. For such behaviour to occur, favourable conditions within an enterprise must also occur. 
The first group of internal factors are microeconomic conditions. As it has already been noted, decisionmaking processes of owners and managers may be influenced by the narrowly understood economic balance, and then green practices may be one way of maximizing short-term profits. In the recent years, the amount of capital invested in clean energy has been growing rapidly (Bloomberg, 2020). The attitude of investors has also been changing as green subsidies grew stingier (The Economist, 2019). More and more often, stock exchange indexes containing environmental components (e.g. the Sustainability Index) are a database used by investors relying on the Environment, Social, Governance (ESG) criteria in decision-making processes. Durand et al. (2019) pointed out that $78 \%$ of analysts take ESG performance into consideration in their investment decisions, according to the CFA Institute. Investors also increasingly respond to the content of enterprises' reports concerning CSR (Aureli et al., 2020). On the other hand, microeconomic factors may be an incentive to demonstrate pro-environmental behaviour.

The average employment time of managers is decreasing (Forbes, 2020; Harvard Law School Forum, 2020), managers' salaries are usually linked to enterprises' financial results, and their components are often share options. With favourable external practices detrimental to the environment, individual managerial targets related to salary levels and a short term perspective can lead to unethical environmental actions. Furthermore, it should be borne in mind that the relationship between the environmental behaviour of stakeholders and the valuation of company shares is still not fully clarified (Durand et al., 2019). As a consequence, one of the most important factors for unethical environmental behaviour in an enterprise is a deficit or lack of ethical leadership. The literature on workplace ethics often emphasises the importance of adapting systems and processes to organizational values and the role of leadership in the development of an ethical culture (Treviño et al., 2018). The study by Boiral et al. (2018) shows that managers' pro-environmental awareness has a positive impact on civic behaviour in this area, i.e. ecoinitiatives and eco-assistance. Pro-environmental behavioural patterns are also influenced by actions and expectations of other relevant people (Collado et al., 2019; Lauren et al., 2019).

The lack of appropriate values, standards, behavioural patterns, and ethical leadership are conducive to unethical behaviour, but such factors as the absence of a sense of guilt and shame about such behaviour (Schneider et al., 2017), a tendency to take risks (Yiannakoulias et al., 2020), as well as moral and ethical implications of environmental restoration (Damian et al., 2019) also play an important role.

\section{Proposed directions of further research}

This paper allows one to raise a number of questions indicating further research directions and existing research gaps:

1. To what extent are managers encouraged to set easy-to-achieve objectives by being rewarded for the accomplishment of environmental targets?

2. Does the tendency to make transparent decisions and avoid greenwashing increase along with growing investments?

3. How do managerial factors (e.g. high salaries and short-term employment prospects), modified by the cultural conditions of the management process influence the effectiveness of proenvironmental measures?

4. How does competition between certification bodies and auditors affect the maturity of environmental management systems and environmental performance?

5. Does counter-productive behaviour demonstrated as a result of obtaining a moral license also apply to the natural environment?

\section{Conclusions}

External conditions and factors, mainly legal and economic ones, may contribute to an increase in the occurrence of unethical pro-environmental behaviour. This is particularly evident when there is no international cooperation in the development of legal regulations, when there are various types of political pressure and games, and when only one's own shortterm goals are pursued. Complicated tax systems, subsidies and prices of emission allowances make it quite easy for particularly large, strong enterprises to engage in greenwashing, carbon leakage, offshoring and unethical lobbying.

External conditions increase the likelihood of unethical behaviour, but it must be borne in mind that certain internal conditions and factors must also occur for it to take place. A short-term perspective resulting from the adopted business model, decreasing average employment time of managers in enterprises and their high salaries, in a situation of high insecurity and a lack of social control, may contribute to actions detrimental to the environment being taken by individuals in enterprises. Such attitudes and actions are intensified when there is a lack of control and external reaction. Much depends also on such decision-making factors as a tendency to take risk, a sense of guilt or uncertainty, which are also important for unethical behaviour and further degradation of the environment.

In the occurrence of unethical environmental behaviour, the axiological background to such behaviour plays a fundamental role as the primary cause, that is, value systems considered in the context of environmental ethics and awareness the level of which 
influences the scope and frequency of unethical activities.

\section{References}

1. ADAMS J., HILLER-BROWN F., MOORE H., LAKE A., ARAUJO-SOARES V., WHITE M., SUMMERBELL C., 2016, Searching and synthesising 'grey literature' and 'grey information' in public health: critical reflections on three case studies, Systematic Reviews, 5: 164.

2. ANDREESSEN M., 2004, Offshoring for the right reasons, Network World, 21(13): 62-62.

3. ARON R., SINGH J., 2005, Getting offshoring right, Harvard Business Review, 83(12): 135-143.AURELI S., GIGLI S., MEDEI R., SUPINO E., 2020, The value relevance of environmental, social, and governance disclosure: Evidence from Dow Jones Sustainability World Index listed companies, Corporate Social Responsibility \& Environmental Management, 27(1): 43-52.

4. BARON D., 1995, Integrated strategy: Market and nonmarket components, California Management Review, 37: 47-65.

5. BESHA A., LIU Y., BEKELE D., DONG Z., NAIDU R., GEBREMARIAM G., 2020, Sustainability and environmental ethics for the application of engineered nanoparticles, Environmental Science \& Policy, 103: 85-98.

6. BLOOMBERG, 2020, Surge in offshore wind financing helps, https://about.bnef.com)/blog/late-surge-inoffshore-wind-financings-helps-2019-renewables-investment-to-overtake-2018

(22.03.2020).

7. BLOOMBERG, 2020, One way to slow climate change, https://www.bloomberg.com/news/articles/ 2019-09-19/one-way-to-slow-climate-change-payceos-to-protect-the-planet (02.03.2020).

8. BOIRAL O., RAINERI N., TALBOT D., 2018, Managers' citizenship behaviors for the environment: a developmental perspective, Journal of Business Ethics, 149(2): p. 395-409.

9. BORYS T., 2006, Social exclusion and integration Indicators Analysis - Proposed Cause-and-effect Structured Studies - part IV, Social Exlusion and Integration in Poland - an Indicators - based Approach, UNDP, Warsaw: 61-88.

10. BORYS T., 2014, Environment protection - towards the extension of efficiency category, Challenges of Sustainable Development, eds. Bartniczak B., Rogala P., Ad Rem, Jelenia Góra: 9-19.

11. BORYS G., BORYS T., 2011, Zintegrowana odpowiedzialność biznesu, Ekologiczne uwarunkowania rozwoju gospodarki oraz przedsiębiorstw, ed. FAMIELEC J., Uniwersytet Ekonomiczny, Kraków: 6580 .

12. COLladO S., STAATS H., SANCHO P., 2019, Normative influences on adolescents. Self-reported pro-environmental behaviors: The role of parents and friends, Environment \& Behavior, 51(3): 288-314.

13. CRASWELL J., 2013, Projektowanie badań naukowych, UJ, Kraków.

14. DAHLMANN F., ROEHRICH J., 2019, Sustainable supply chain management and partner engagement to manage climate change information, Business Strategy and the Environment, 28(8): 1632-1647.
15. DAMIAN G., MICLE V., SUR I., CHIRILĂ BĂBĂU A., 2019, From environmental ethics to sustainable decision-making: Assessment of potential ecological risk in soils around abandoned mining areas-case study 'Larga de Sus mine' (Romania), Journal of Agricultural \& Environmental Ethics, 32(1): 27-49.

16. DE JONG M., HARKINK K., BARTH S., 2018, Making green stuff? Effects of corporate greenwashing on consumers, Journal of Business and Technical Communication, 32(1): 77-112

17. DE JONG M., HULUBA G., BELDAD A., 2020, Different shades of greenwashing: consumers' reactions to environmental lies, half-lies, and organizations taking credit for following legal obligations, Journal of Business \& Technical Communication, 34(1): p. 38-76.

18. DURAND R., PAUGAM L., STOLOWY H., 2019, Do investors actually value sustainability indices? Replication, development, and new evidence on CSR visibility, Strategic Management Journal, 40(9): 1471-1490.

19. EASTERBY-SMITH M., THORNE R., JACKSON P., 2015, Management and business research, Sage, Los Angeles-Singapore.

20. EUROPEAN COMMISSION, 2020, https://ec.europa.eu/clima/sites/clima/files/ets/allowances/leakage/docs/cl_evidence_factsheets (28.10.2020).

21. EPTING S., 2018, Philosophy of the city and environmental ethics, Environmental Ethics, 40(2): 99100.

22. FORBES, 2020, Making leadership last, https:// www.forbes.com/sites/cassandrafrangos/2018/12/03/ making-leadership-last-how-long-tenure-ceos-standtheir-ground (03.03.2020).

23. GANOWICZ-BĄCZYK A., 2015, Birth and development of environmental ethics, Studia Ecologiae et Bioethicae, 13(4): 39-63.

24. GATERSLEBEN B., MURTAGH N., CHERRY M., WATKINS M., 2019, Moral, wasteful, frugal, or thrifty? Identifying consumer identities to understand and manage pro-environmental behavior,Environment \& Behavior, 51(1): 24-49.

25. GĄSKA J., PYRKA M., JESZKE R., RABIEGA W., SEKUŁA M., 2019, Carbon Leakage in the context of increasing the EU greenhouse gas emission reduction targets - the ways the EU and global emission behave and what influences its scale, Ochrona Środowiska i Zasobów Naturalnych, 30(2): 6-23.

26. GURTU A., SEARCY C., JABER M., 2016, A framework for reducing global manufacturing emissions, Journal of Environment \& Development, 25(2): 159-190.

27. HARVARD LAW SCHOOL FORUM ON CORPORATE GOVERNANCE, 2020, https://corpgov.law. harvard.edu/2018/02/12/ceo-tenure-rates (04.03.2020).

28. JONES E., KENNEDY E., JOHNSTON J., 2019, Rethinking greenwashing: Corporate discourse, unethical practice, and the unmet potential of ethical consumerism, Sociological Perspectives, 62(5): 728-754.

29. JORDAN T., GARLAND J., OWUSU-NYAMEKYE D., 2014, Globalization and international outsourcing trends in an emerging power: The case of India, Journal of Global Intelligence \& Policy, 7(13): 87-103. 
30. KELLER D., 2012, Introduction: What is environmental ethics? Environmental ethics: the big questions, ed. KELLER D., Wiley-Blackwell, London.

31. KELLY S., NOONAN C., 2008, Anxiety and psychological security in offshoring relationships: the role and development of trust as emotional commitment, Journal of Information Technology, 23(4): 232-248.

32. KIM J., 2019, Is your playing field unleveled? U.S. defense contracts and foreign firm lobbying, Strategic Management Journal, 40(12): 1911-1937.

33. KINZIG A., EHRLICH P., ALSTON L., ARROW K., BARRETT S., BUCHMAN T., DAILY G., LEVIN B., LEVIN S., OPPENHEIMER M., OSTROM E., SAARI D., 2013, Social norms and global environmental challenges: The complex interaction of behaviors, values, and policy, BioScience, 63(3): 164-175.

34. KONSTAŃCZAK S., 2008, Etyka środowiskowa, Stownik bioetyki, biopolityki i ekofilozofii, ed. Ciszek D., Polskie Towarzystwo Filozoficzne, Warszawa.

35. LABOUTKOVÁ Š., VYMĚTAL P., 2019, A new approach in evaluation of transparent lobbying - the case of Visegrad group countries, Administration \& Public Management Review, 33: 119-132.

36. LAUREN N., SMITH L., LOUIS W., DEANET A., 2019, Promoting spillover: How past behaviors increase environmental intentions by cueing self-perceptions, Environment \& Behavior, 51(3): 235-258.

37. LEE H., CRUZ J, SHANKAR R., 2018, Corporate Social Responsibility (CSR) issues in supply chain competition: Should greenwashing be regulated?, Decision Sciences, 49(6): 1088-1115.

38. LI X., ZHOU Y., 2017, Offshoring pollution while offshoring production? Strategic Management Journal, 38(11): 2310-2329.

39. LOCK I., SEELE P., 2016, Deliberative lobbying? Toward a noncontradiction of corporate political activities and Corporate Social Responsibility?, Journal of Management Inquiry, 25(4): 415-430.

40. MORE P., 2019, The impact of greenwashing on green brand trust from an Indian perspective, in: Asian Journal of Innovation \& Policy, 8(1): 162-179.

41. NAEGELE H., ZAKLAN A., 2019, Does the EU ETS cause carbon leakage in European manufacturing?, Journal of Environmental Economics \& Management, 93: 125-147.

42. PAPUZIŃSKI A., 2006, Ecological awareness in the light of theory and practice (an outline of a politicalscience model of ecological awareness), Problemy ekorozwoju/ Problems of Sustainable Development, 1(1): 33-40.

43. PASSMORE J., 1974, Man's responsibility for nature: ecological problems and western traditions, Charles Scribner's Sons, New York.

44. ROLSTON H., 2012a, A new environmental ethics. The next millenium for life in Earth, Routledge, New York-London.

45. ROLSTON H., 2012b, The future of environmental ethics, Environmental ethics: the big questions, ed. Keller D., Wiley-Blackwell, London: 561-574.

46. SAFARI A., SALEHZADEH R., PANAHI R., ABOLGHASEMIAN S., 2018, Multiple pathways linking environmental knowledge and awareness to employees' green behavior, Corporate Governance: The International Journal of Effective Board Performance, 18(1): 81-103.
47. SANTOS L., GARAFFA R., LUCENA A., 2019, Would different methodologies for assessing carbon leakage exposure lead to different risk levels? A case study of the Brazilian industry, Climate Policy, 19(9): 1102-1116.

48. SCHMUCK D., MATTHES J., NADERER B., 2018, Misleading consumers with green advertising? An affect reason involvement account of greenwashing effects in environmental advertising, Journal of Advertising, 47(2): 127-145.

49. SCHNEIDER C., ZAVAL L., WEBER E., MARKOWITZ E., 2017, The influence of anticipated pride and guilt on pro-environmental decision making, PLOS ONE, 12(11): p. 1-14.

50. SIMPSON W., KOHERS T., 2002, The link between Corporate Social and financial performance: evidence from the banking industry, Journal of Business Ethics, 35(2): 97-109.

51. SKOLIMOWSKI H., 1981, Eco-philosophy: designing new tactics for living, Marion Boyars Publishers, London.

52. SOMMER M., KRATENA K., 2020, Consumption and production-based $\mathrm{CO}_{2}$ pricing policies: macroeconomic trade-offs and carbon leakage, Economic Systems Research, 32(1): 29-57.

53. STABLES A., 2020, Environmental ethics and ontologies: Humanist or posthumanist? The case for constrained pluralism, Journal of Philosophy of Education, 54(4): 888-899.

54. SUN Y., XUE J., SHI X., WANG K., QI S., WANG L., WANG C., 2019, A dynamic and continuous allowances allocation methodology for the prevention of carbon leakage: Emission control coefficients, $A p$ plied Energy, 236: 220-230.

55. SUN Z., ZHANG W., 2019, Do government regulations prevent greenwashing? An evolutionary game analysis of heterogeneous enterprises, Journal of Cleaner Production, 231: 1489-1502.

56. ŚWIAT OZE, 2020, Greenwashing, https://www. swiatoze/greenwashing-czyli-ekosciema (18.10. 2020).

57. TAYLOR M., 2005, Unbundling the pollution haven hypothesis. The B.E., Journal of Economic Analysis \& Policy, 4 (2): 1-28.

58. TESTA F., BOIRAL O., IRALDO F., 2018, Internalization of environmental practices and institutional complexity: Can stakeholders pressures encourage greenwashing? Journal of Business Ethics, 147(2): 287-307.

59. THE ECONOMIST, 2019, The not so dirty dozen, September 21th: 65 .

60. THE ECONOMIST, 2020, Sustainable investing. Green giant, January $18^{\text {th }}: 70$.

61. THE GUARDIAN, 2020, Carmakers accused of using COVID-19 weaken environmental laws, https://www.theguardian.com/business/2020/mar/27/ carmakers-accused-of-using-covid-19-weaken-environmental-laws (29.03.2020).

62. THE GUARDIAN, 2020, Green executive compensation, https://www.theguardian.com/sustainable-bus iness/2014/jun/26/green-executive-compensation-intel-alcoa-pay (2.03.2020).

63. THE GUARDIAN, 2020, World may miss carbon targets, unless big firms improve, https://www. theguardian.com/environment/2020/feb/27/worldmay-miss-carbon-targets-unless-big-firms-improvemark-carney (09.03.2020). 
64. TOMIURA E., 2009, Foreign versus domestic outsourcing: Firm-level evidence on the role of technology, International Review of Economics \& Finance, 18(2): 219-226.

65. TOPAL İ., NART S., AKAR C., ERKOLLAR A., 2020, The effect of greenwashing on online consumer engagement: A comparative study in France, Germany, Turkey, and the United Kingdom, Business Strategy \& the Environment, 29(2): p. 465-480.

66. TORELLI R., BALLUCHI, F., LAZZINI, A., 2020, Greenwashing and environmental communication: Effects on stakeholders' perceptions', Business Strategy \& the Environment, 29(2): 407-421.

67. TREVIÑO L., BROWN M., 2005, The role of leaders in influencing unethical behavior in the workplace managing organizational deviance, Management and Organization, 5: 69-96.

68. QIAO A., CHOI S., WANG X., 2019, Lot size optimisation in two-stage manufacturer-supplier production under carbon management constraints, Journal of Cleaner Production, 224: 523-535.

69. UMPHRESS E., BINGHAM J., 2011, When employees do bad things for good reasons: Examining unethical pro-organizational behaviors, Organization Science, 22(3): 621-640.

70. VAN DER PLOEG F., 2016, Second-best carbon taxation in the global economy: The Green Paradox and carbon leakage revisited, Journal of Environmental Economics \& Management, 78: 85-105.

71. WHITBURN J., LINKLATER W., ABRAHAMSE W., 2020, Meta-analysis of human connection to nature and proenvironmental behavior, Conservation Biology, 34(1): 180-193.

72. WINSTON A., 2019, Corporate action on climate change has to include lobbying, Harvard Business Review, October $15^{\text {th }}: 2-5$.

73. YIANNAKOULIAS N., GORDON J., DARLINGTON J., 2020, The decision game: a serious game approach to understanding environmental risk management decisions, Journal of Risk Research, 23(1): 8194.

74. ZHANG S., 2020, Workplace spirituality and unethical pro-organizational behavior: The mediating effect of job satisfaction, Journal of Business Ethics, 161(3): 687-705.

75. ZHANG Q., FANG K., 2019, Comment on "Consumption-based versus production-based accounting of $\mathrm{CO}_{2}$ emissions: Is there evidence for carbon leakage?", Environmental Science \& Policy, 101: 94-96.

76. ZHANG W., WANG W., WANG S., 2014, Environmental performance evaluation of implementing EMS (ISO 14001) in the coating industry: case study of a Shanghai coating firm, Journal of Cleaner Production, 64: 205-217. 